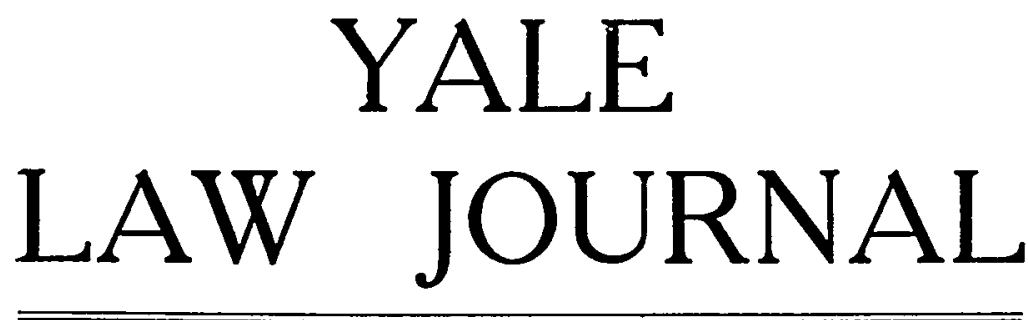

Vol. XVIII JUNE, 1909. No. 8

\title{
DEVELOPMENT OF SECONDARY RIGHTS IN TRADE MARK CASES
}

Lord Bowen once sagely remarked: "Law should follow business." 1 The history of the law is replete with examples of its recognition of this duty. One of these may be found in the early history of the law merchant in England. This system of law, as is of course well known, was a series of customs employed by merchants in mercantile transactions. It contained at least three doctrines foreign to the common law, which, being a hard and fast system, naturally felt an aversion to the foreign intruder. But even the inelastic common law was compelled to follow business, and to allow the law merchant to become a vital force in the legal system of England, modified in external appearance, it is true, by certain fictions and engrafted forms.

Perhaps a better example of the remark quoted is found in the growth of patent and trade-mark law in the United States. The history of the law of patents runs back to the royal grants of monopolies in England. The colonies on this side of the Atlantic, for the most part, recognized the necessity of granting patent rights, and among the first of the constitutional grants to Congress is the power of securing to inventors for a limited time the exclusive right to their inventions. Under the stimulus of this protection thus given, the inventors of America rapidly gave to the world such epoch-making inventions as the cotton-gin, the harvester, the telegraph, the telephone and the electric light.

\footnotetext{
1 Bigelow, Bills, Notes and Cheques, and ed., p. 7.
} 
The use macle of these inventions has produced an expansion of business which is one of the most remarkable achievements of the last and present centuries.

This expansion of business demonstrated the value of patent and trade-mark rights. The profits accruing to the several own. ers of the patents and the manufacturers of their inventions led many to imitate and to seek by devious and unfair means to draw to themselves a part of the profits thus being won. To rencler more secure the possession of their rights, manufacturers, and merchants in general, early in the history of our commercial era came to employ certain arbitrary marks by way of a trademark. Men of business clearly perceived the value of such marks, and that a right of property might be secured therein. As early as 1742, the question was raised in an English case, wherein an injunction was sought to restrain one trader from using the same mark as another, and it is to be clearly noted that such injunction was denied." Some half a century later, however, Lord Mansfield asserted the rights of property in a trademark, and granted an injunction to protect such right. ${ }^{3}$

From this beginning in England there grew up both in that country and in ours a considerable body of law dealing with the subject of trade-marks, defining what may be and what may not be a valid trade-mark, and under what circumstances an injunction may issue to preserve to a given manufacturer or merchant, the proprietary right in an arbitrary sign which he claims as a trade-mark. It is comnion knowledge that this branch of the law has been noticeably technical and narrow. The law was feeling its way along the path which had been previously established by business, but for many years it was a long way behind. Courts at first felt the necessity of finding a trade-mark in the technical sense before granting relief. Other courts refused relief in cases where arbitrary marks or signs had been used on the ground that they were employed by manufacturers or merchants to distinguish grade or quality rather than a particular source of manufacture. Finally, in 1877 , a beginning was made to break away from the previous technical interpretation of the law. In other words, business was beginning to influence law, and to compel the latter to approach more nearly to the former's

2 Blanchard v. Hill, 2 Atkyn's Reports, 484 .

3 Singlcton v. Bolton, 3 Douglas's Reports, 393. 
necessities. At the risk of stating matters already known by the majority of lawyers, I quote brifly from what is consiclered to be the fundamental opinion in the United States. The sentences commonly referred to are these: "Nor is it necessary, in order to give a right to an injunction, that a specific tracle-mark should be infringed; but it is sufficient that the court is satisfied that there was an intent on the part of the respondent to palm off his goods as the goods of the complainant, and that he persists in so doing after being requested tc desist." " Six years later, this doctrine was reiterated and more firmly grounded in a state court's opinion."

There are, then, two kinds of protection afforded every manufacturer or merchant who is building up a business reputation of value, regardless of how large or small his business may be.

Ist. There is the technical trade-mark, which is the fanciful application of some new or old name or mark to a particular line of goods which is being advertised. These marks are protected by federal and state statutes if properly registered. There are a great many limitations to technical trade-marks, owing to the fact that under the statutes and rulings of the courts, these trade-marks must not be descriptive, geographical or deceptive words.

2nd. There is the trade name, label, or design, established by every manufacturing company through its use of that name, label, or design in the selling of its goods, and this trade name, label, or design, which may be geographical or otherwise, coupled with what is known as the doctrine of unfair trade, is a broader and more efficient means of protecting the ordinary manufacturer or merchant.

The foregoing traces historically the growth of the law to the beginning of the modern doctrine of unfair trade. The entire theory of the law of trade-marks has always been that no man should be permitted to palm off his goods as those of another. By means of trade-marks, a certain degree of protection had been given. As shown, however, this protection was very inadequate, and in some instances could not be invoked at all. For example, during the life of a valid trade-mark an extensive business might be built up by judicious advertising and honorable clealing. With

1 McLcan v. Flcming, 96 U. S. 245.

5. Avery v. Mcikle, 8I Ky. 75. 
the expiration of the trade-mark right, this good will and established business would become entirely lost to its fcrmer owner; or a party might build up an extensive business upon goods which were identified by some peculiarity of shape or style of wrapper, or the distinctive mark placed upon his goods might be a geographical name, or the name of an individual. In these latter instances, the technical law of trade-marks would not afford protection or relief against dishonest practices of unscrupulous competitors. Competition does not justify this situation. The common law has always been a friend of competition. But competition must be honest, and a dishonest competition is one form of fraud. In seeking the principle by which relief might be granted in a case of unfair competition, a unique and peculiar doctrine has been evolved by the courts. This doctrine is, that words in common use, geographical terms or proper names, while they may not be appropriated exclusively in their primary meaning, may come to have a secondary meaning which legitimately belongs exclusively to the person who has created and developed that meaning. In such meaning of such term, there is held to be a property right. For illustration, a new manufacturer by the name of Baker begins the manufacture of thocolate. He has the undoubted right to label in some way his wares with his own name. There can be no exclusive appropriation of the proper name Baker. In marketing his wares, however, he is not allowed to label them "Baker's Chocolates," if this connotation of words has been previously appropriated by another Paker, and has come to identify in the minds of the pttblic generally the chocolate manufactured by the original manufacturer. The new manufacturer may label his package, "Made by Baker," ${ }^{\circ}$ but not "Baker's Chocolates," and his sty!e of wrapper or package must not simulate that of the first Baker. Another illustration which may serve to make this clear is the instance of the Waltham Watch, manufactured originally by an inhabitant of that city, and labelled with the proper name of "Waltham." There can be no exclusive appropriation of the geographical name "Waltham," and any other inhabitant of that city is at liberty to engage in the manufacture of watches, but he cannot make use of the term "Waltham" in such a way as to lead the public to believe that his watch is that of the original manufacturer. The term "Waltham,"

- Walter Baker Co. v. Sanders, 80 Fed. 889. 
as applied to a watch, has come to have a secondary meaning, and identifies in the mind of the public the watch of the first producer.

There are numerous illustrations where one manufacturer, striving to gain advantage over some other manufacturer, has sold his business and his reputation to another manufacturing concern, and then within a short period of time has commenced to manufacture similar goods in the same town or same locality, and in this manner gains advantage which is entirely unfair, which, in my judgment, is the worst form of illegitimate competition.

Another instructive example of the application of the doctrine of unfair trade is seen in the case of a manufacturer whose patent has expired. It is in such a case that the doctrine of unfair trade, founded upon the secondary meaning of a word or name, applied to an article of manufacture, manifests its perfect work. For example, a manufacturer may place upon the market a patented article, which he calls the Singer Sewing Machine. After the expiration of the patent another manufacturer has the right to make and sell an article of the same form. Furthermore, he has the right to use the term "Singer," as applied to his machine. The doctrine of unfair trade, however, places this restriction upon him, viz: that he must in some adequate way clearly distinguish his article from that made by the original manufacturer. ${ }^{\text {? }}$

The only fair and legitimate way of utilizing a ready selling article or device, the demand for which has been established, is for the new manufacturer to so dress that device, so name, and so advertise it as to distinguish it clearly and distinctly from the one which is already in the field, and which is entitled to its own reputation, and by this distinct method, create a demand, and by originality of thought, build up a reputation for his own goods which will outstrip all competition, and eliminate him from becoming an imitator and a parasite, who would feed upon the reputation of another.

The cases cited, and many others which might be quoted, show how some American courts have applied the doctrine of unfair competition. In these cases, it is held, there must appear, first, that the complainant has built up a valuable business, and that

${ }^{7}$ Singer Mfg. Co. v. June Mfg. Co., 163 U. S. I6g. 
there is some particular word, name or characteristic applied to his wares, which serves to identify them in the minds of the public as being of his manufacture; second, it must appear that the defendant, by an imitation of complainant's mark or name, has sought to create the impression that his wares are of the complainant's manufacture; and third, the public must be deceived by this pretense. Some courts lay great stress upon the fact that in an unfair competition case there must be alleged and proved the fraudulent intent on the part of the defendant. As is said in one case: "This suit is based on fraud. Its foundation is unfair, fraudulent competition, and the intent to deceive is an indispensable element of the fraud which warrants the relief sought. This intent, and the fraud in which it inheres, may be, and generally must be, proved by circumstances, by facts, by sales, by a course of action; but the facts and circumstances which establish it must be such that the fraud and the intent to deceive the public are fairly inferable from them." 8

Whatever the courts mean by this or similar language, on principle it should be sufficient if the defendant's goods, as they appear when placed on the market, deceive. This being true, evidence ought not to be required to prove an intent to deceive. If the average reasonable man would be deceived by the simulated appearance of the defendant's goods, then the defendant should be conclusively presumed to have intended a deception, and this is tantamount to saying that intent should not form a determining element in a case of unfair competition. It is also said that the public must be deceived. This, doubtless, is based upon the assumption that damages must be proved by the complainant before he can maintain his cause of action and secure an injunction. If it means that the public must be actually damaged in the sense that inferior goods are foisted upon it in place of complainant's articles of superior merit, then the proposition is unsound. For example, it is conceivable that a dealer of a secret preparation might have his wares compounded by a given chemist, and that another business rival might secure the identical preparation from the same chemist, and place it upon the market. The public, in such a case, would receive from both dealers the same article, but an action for unfair competition should lie, if the business rival has so labelled or wrapped his article that the pub-

sGorham Mfg. Co. ''. Entry-Bird-Thayer Drygoods Co., I4o Fed. 243. 
lic believe it to be the article which has been previously purchased from the original dealer. In 1877 , an American writer, speaking of the doctrine under consideration, said: "The interference of courts of equity, instead of being founded upon the theory of protection to the owner of trade-marks, is now supported mainly to prevent frauds upon the public." ${ }^{9}$ This, it is submitted, is not the way in which business regards the problem, nor is it the way in which the law should approach the question. In seeking to give the complainant relief, neither the mental attitude of the defendant, nor the position of the public should be regarded as necessarily determinitive. The primary question should be: "Has the defendant sought to palm off upon the public his goods as being the goods of the complainant?" If that is the case, then an injunction should issue.

It has been said that "The law should follow business." A business may be almost world-wide in scope, or it may be confined to a comparatively restricted area. If the doctrine of unfair trade is to meet business necessities, it must also be elastic and broad enough to protect trade wherever found, and irrespective of its extent. For example, there may be a case in which a local cigar manufacturer is placing on the market, within a limited territory, a brand of cigars bearing a particular label. In the case in question, the label was the word "She," in large letters, pasted upon the inside of the box. These labels were not designed by the manufacturer of the cigars, but were a stock label. purchased from a manufacturer in New York, who had made the same for sale generally to dealers. The complainant dealer had purchased a number of these labels, and, as the exclusive ilealer in "She" cigars in this locality, had put upon the market a large quantity of cigars of this brand. The sale of these cigars was confined to a number of counties in a given state. The defendant purchased a number of the same labels, and put upon the market a brand of "She" cigars in the same locality. The court in granting an injunction says: "But aside from the law of trade-marks, courts will protect trade names or reputations, although not registered or properly selected as trade-marks, on the broad ground of enforcing justice and protecting one in the fruits of his toil. This is all bottomed on the principle of common business integrity, and proceeds on the theory that, while the primary and com-

${ }^{\circ}$ Coddington Digcst, Sec. 36 . 
mon use of a word or phrase may not be appropriated exclusively, there may be a secondary meaning or construction which will belong to the person who has developed it. Its this secondary meaning, there may be a property right." ${ }^{10}$ An injunction was granted to protect complainant against unfair competition, although his trade was restricted territorially.

In view of what has been said, it would perhaps be thought that the doctrine of unfair competition is fully developed and well understood by the courts. True, it is comparatively a new doctrine, but business expansion in the last forty years has been so rapid that very many cases have come before the courts for adjudication, and a number of excellent precedents have been established. Many courts have treated the question conscientiously and broadly, and have planted their decisions upon the rock of commercial integrity and honor. It must not be thought, however, that the doctrine is yet fully grown or perfectly understood, for it is still in its infancy. Not infrequently may be found a decision which appears to show little or no comprehension of the broad features of the doctrine, or of its relation to the expanding needs of a commercial world. In a very recent case ${ }^{12}$ the majority of the court seems to have absolutely missed the point at issue, and to have taken a distinct step backward, rather than to the front. The facts of the case are these: In I89I, the complainant commenced to make and put upon the market a prepared roofing material of felt, saturated with a gum composed of the residuum of animal fats. The product resembled rubber, and the name "Ruberoid" was applied as a trade-mark, and was duly registered in the U. S. Patent Office in Igor. An extensive business was built up by advertising and otherwise. In 1904, the defendant put upon the market a roofing of similar appearance and composition, except that vegetable oils were used in treating the felt, instead of animal fats, and applied the name "Rubber-O" thereto. Complainant's attorney, recognizing the growth of the doctrine of unfair competition, brought his action, as is frequently done of late, upon two grounds: First, infringement of trade-mark; and, second, unfair competition, in that the defendant, by the use of the word "Rubber-O," had put upon the market a product calculated to deceive the public, when

10 Sartor v. Schadcn, 125 Iowa, 696.

${ }^{11}$ Trinidad Asphalt Mfg. Co. v. Standard Paint Co., I63 Fed. 977. 
buying it into the belief that they were buying the roofing of the complainant. To the very great credit of the trial court, it must be said that the complainant had a decree. On appeal, the Circuit Court of Appeals of the Eighth Circuit reversed the decision of the trial court, and ordered the bill dismissed. The astounding ground of this decision is, first, that "Ruberoid" cannot be appropriated as a trade-mark for a roofing such as complainant had manufactured. This was held to be so for the reason that it is merely a mis-spelling of "Rubberoid," which is a common descriptive term, the use of which belongs to the public. The soundness of the decision on this point may well be questioned; but it is not the part of the court's holding which is most subject to criticism. In dealing with the complainant's second count, the court employs this language: "We discover nothing in defendant's conduct justifying the charge of unfair competition. In the last analysis, the charge rests solely on the use of the word 'Rubber-O' and the similarity thereof to 'Ruteroid,' or its equivalent, rubberoid. *** The word rubberoid is part of the common heritage, and all who can truthfully apply it to their products are entitled to do so, taking due care that they do not otherwise trespass on the rights of competitiors. The defendant being entitled to the proper use of the word rubberoid, the complainant cannot justly complain of the use of 'Rubber-O.' "

From the above quotation, it will be seen that the court entirely ignores the secondary signification of the word "Ruberoid," in that such term had come to mean, in the minds of the public, a roofing of complainant's manufacture, and by so doing, practically destroys the trade reputation of an enormous industry by allowing it to be pirated. The evidence showed conclusively that the public had been. misled by the defendant's use of the word "Rubber-O," complainant's sales having decreased eight thousand dollars in the territory where the latter article was sold, and nowhere else. This was found as a fact by the lower court, and should have been conclusive to establish the fact that the public was misled by the defendant's term "Rubber-O." The only discoverable basis upon which the appellate court's decision may be rested with any degree of propriety grows out of the fact that defendant stamped upon its roofing its name as manufacturer. All these matters are dealt with in a thoroughly effective way by the dissenting opinion. It is there said: "The striking simi- 
larity between the words 'Rubber-O' and 'Ruberoid'; the many dissimilar names open to the defendant, the long established reputation and extensive sales of complainant's 'Ruberoid,' the evident probability and the evidence of confusion of the trade by the use of the word 'Rubber-O' and the decrease of the complainant's sales after the defendant commenced to use it, leave no doubt in my mind that the court below was right in its conclusion that the purpose of the conception and use of the word 'Rubber- $O$ ' by the defendant, was to palm off its product as that of the complainant, and that it has been accomplishing this purpose." Answering the suggestion that "Ruberoid" and "Rubberoid" are the same, the learned judge says: "Ruber-oid' sounds as different from 'rubberoid' as 'ruble' from 'rubble.' It was not spelled in the same way, and when written or printed it had a strikingly different appearance. There is no more striking method of differentiating words than by changing the spelling. Witness 'uneeda' in contrast with 'youneeda.' The absence of a single letter destroys the identity and the similarity of appearance and signification of many words. 'Tough' is not 'trough:' 'cow' is not 'crow ;' 'rob' is not 'robe ;' 'robin' is not 'robbin ;' 'robing' is not 'robbing;' 'ruble' is not 'rubble ;' and 'ruberoid' is not 'rubberoid." "

The effect of the dissenting judge's reasoning is certainly hard to overcome, but even granting that "ruberoid" is not subject to valid appropriation as a trade-mark, still complainant should win. For as is further pointed out in the dissenting opinion, "it is the duty and practice of courts of equity to enjoin the use of descriptive and geographical terms by one competitor for the purpose of filching the trade of another," citing numerous authorities. Further, "the general rule is that one may not use his own name even to sell his goods as those of another." These are well known propositions to one familiar with the general principles of the law of unfair trade, and demonstrate that the dissenting judge is right, and the majority opinion almost absurdly wrong. A failure to appreciate business needs subjects the enterprises of the entire country to the hazard of a rule, unjust, illogical and wrong, as above pointed out, particularly when the judge below, who should be judge of the facts, and, in addition, an able dissenting judge, holds that a case of unfair competition was made out, although an equal number of judges who 
happened, by virtue of their position, to be in control of the situation, hold that no rights had been violated by these unfair trade methods. But, happily, such decisions are becoming less frequent, and it is to be hoped this unfair precedent will not be followed.

The law is following business more closely all the time. Whether a man's tracle is country-wide, state-wide, or worldwide, the law should and does in an increasing degree protect him in that trade. We can now congratulate ourselves that no other development of any branch of the law is based so much on the business integrity, common honesty and justice as this climax of trade-mark law, known as the law of unfair competition, particularly in its secondary sense. This principle of the law strives to prevent all manufacturers or dealers, starting into new enterprises, from using articles dressed similarly to those already on the market, whether in design or label, or design of goods, prevent the use of advertising literature or cuts resembling those of an old manufacturer or dealer, and, most of all, obviate, if possible, the selling out to another concern of an enterprise and afterwards establishing a business in the same locality in the same line with an intention at the time of gaining benefit as a result of the former reputation built up by the seller, and his previous business experience, and which is now legitimately owned by the one to whom he sold. Unless both maker and purchaser can count on an impartial enforcement of this principle, neither the manufacturer nor the dealer can win and maintain a reputation, nor the purchaser rely upon the advertising by_which he purchases his goods.

It is not urged that the doctrine of unfair competition be carried to extremes. In this day of monopolies and trusts, the public is a quasi-party to every suit involving a business enterprise, and the rights of such party must be safeguarded. However, there is little likelihood of discouraging legitimate business, so long as the doctrine of unfair trade compels each man, so far as competition with his fellow is concerned, to stand or fall by his own merit and ingenuity.

In this state of the development of the law of unfair trade, it is sincerely to be hoped that there will be no suggestion made that the law be codified. We have at present a broad, general, elastic doctrine. It is being adapted to the needs of modern business in a reasonably successful manner. As the needs of business change, 
so may this doctrine be changed. It will be remembered that the Trade Mark Act of July, 1870, was declared unconstitutional. ${ }^{12}$ It will also be recalled that under the United States Trade-Mark Registration Act of $188 \mathrm{r}$, there were many enterprises built up in the United States. This law was, in $1903,{ }^{13}$ declared so limited in scope, so far as protection of trade was concerned, as to be practically futile; so much so that the old law was repealed, and in April, 1905, a new statute enacted, which in its scope does not adequately meet business conditions. Modern business should be subjected to no more hazards of a similar character; but the law of unfair trade should be allowed to take its normal course of development, being applied, as each case arises, by careful, wellinformed judges, who are alive to the truth of the saying: "The law should follow business."

Wallace R. Lane.

12 Trade Mark Cases, 100 U. S. 82.

12 Warner v. Searle \& Hereth Co., 19I U. S. 195. 